\title{
PENGEMBANGAN PEMBELAJARAN SAINS BERORIENTASI IMAN DAN TAQWA
}

\author{
H. Wildan \\ Prodi. Pendidikan Kimia PMIPA FKIP Universitas Mataram \\ Jl. Majapahit No. 62 Mataram 83125
}

\begin{abstract}
Abstrak. Meningkatkan IMTAQ selalu muncul pertama sebagai tujuan pendidikan sains dalam setiap kurikulum pada semua jenis dan jenjang pendidikan. Namun, upaya guru untuk mengembangkan pembelajaran yang berorientasi kepada IMTAQ masih sangat sedikit, buku-buku pelajaran sains yang mengkaitkan antara materi sains dengan aspek imtaq sangat sedikit, kemampuan dan kemauan guru untuk mengembangkan pembelajaran berorientasi imtaq masih sangat kurang. Karena itu, guru dan/atau calon guru sains harus membekali dirinya, tidak hanya dengan penguasaan materi, pendekatan dan strategi pembelajaran yang cangkih, tetapi juga dengan menambah wawasan tentang pembelajaran (sains) yang berorientasi kepada imtaq, dan yang paling utama adalah kesadaran bahwa guru adalah profesi nurani.
\end{abstract}

Kata Kunci: Pembelajaran Sains, Imtaq

\section{DEVELOPMENT OFTEACHINGOF SCIENCE BASED ONIMANAND TAQWA}

\begin{abstract}
Improving IMTAQ is always being the main objective of science education in every curriculum of all level of education. The teachers' efforts to develop the IMTAQ-oriented teaching and learning, however, are very limited. Science books that relate the science with the IMTAQ aspect also very little. The teachers capacity and knowledge to develop the IMTAQ-oriented teaching materials is far from sufficient. For that purpose, teachers and teachers candidate should equip themselves not only with the material along with shopisticated teaching approaches and strategies, but also by exstending their ideas on teaching science that is oriented to improving the students' IMTAQ, and by realizing that being teacher is heart-called profession.
\end{abstract}

Keywords: Teaching Science, Imtaq

\section{PENDAHULUAN}

Ilmu pengetahuan dan teknologi (IPTEK) telah dan akan mengalami perkembangan yang sangat pesat yang memberikan dampak pada semua aspek kehidupan manusia. Salah satu dampak yang paling meresahkan berbagai kalangan adalah sudah mulai nampak gejala tumbuhnya suatu kelompok (generasi) yang beranggapan bahwa sains dan agama tidak ada kaitannya yang memanfaatkan hasil IPTEK dengan tidak mengindahkan etika agama dan kemanusiaan, dan sangat bangga dengan ilmu yang dikuasainya, manusia sombong bahkan menjadi manusia yang tidak mempercayai adanya Tuhan Yang Maha Kuasa.

Nature dalam Effendy [1], menyebutkan bahwa dari tahun ke tahun, jumlah ilmuwan besar yang percaya kepada Tuhan YME semakin berkurang dari 27,7\% pada tahun 1914 menjadi 7,00 \% pada tahun 1998. Sementara mereka yang tidak percaya adanya Tuhan YME semakin meningkat dari 52,7 \% pada tahun 1914 menjadi 72,2\% pada tahun 1998, dan mereka yang ragu-ragu terhadap keberadaan Tuhan YME sebanyak 20,9\% pada tahun 1914, turun menjadi 17 $\%$ pada tahun 1933 dan naik kembali menjadi 20,8\% pada tahun 1994. Grafik perkembangan kepercayaan ilmuwan terhadap Tuhan YME.
Dalam dokumen tentang pembangunan pendidikan [2], seperti dalam rencana strategis hingga kurikulum sains pada semua jenjang pendidikan selalu disebutkan bahwa tujuan pendidikan (sains) antara lain disebutkan: (1) menumbuhkankembangkan keimanan dan ketaqwaan kepada Tuhan YME berdasarkan keberadaan, keindahan dan keteraturan alam ciptaan-Nya, (2) memberi bekal yang cukup bagi siswa untuk berhasil dalam berbagai ujian, dan (3) memberi bekal bagi siswa untuk memasuki dunia kerja dan hidup yang layak di masyarakat apabila tidak dapat melanjutkan pendidikan ke jenjang yang lebih tinggi.

Pencapaian tujuan-tujuan pendidikan di atas melibatkan banyak komponen yang dikenal dengan istilah instrumental input. Dua di antaranya yang terpenting adalah kurikulum dan guru. Tujuan kedua, yaitu memberi bekal yang cukup kepada peserta didik agar dapat lulus ujian akan tercapai dengan baik, bilamana pembelajaran yang dilakukan berdasarkan kurikulum yang telah ditetapkan secara tepat, guru mengusai materi pembelajarannya dengan benar dan tidak salah konsep, guru mampu memilih pendekatan, strategi, dan metode pembelajaran yang sesuai dengan tujuan dan sifat materi, serta mampu mengembangkan alat 


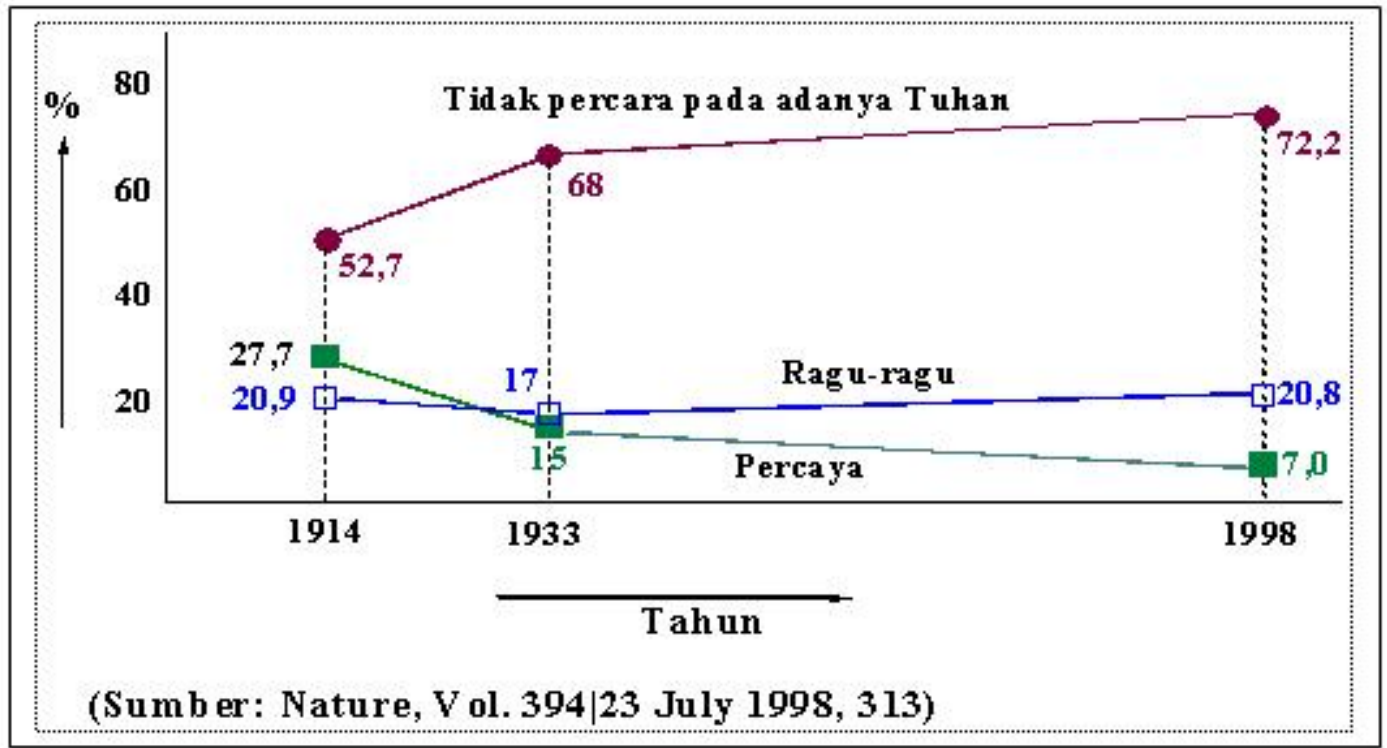

evaluasi yang setara dengan alat evaluasi pada berbagai ujian, baik di sekolah maupun ujian pada tingkat nasional.

Tujuan yang ketiga, yaitu memberi bekal yang cukup untuk dapat memasuki dunia kerja dan hidup layak di masyarakat terutama bagi siswa yang tidak dapat melanjutkan belajar ke pendidikan yang lebih tinggi, akan tercapai bilamana guru mampu mengajarkan mereka dengan berbagai ketrampilan, baik ketrampilan akademik maupun ketrampilan vokasional, seperti ketrampilan sablon, fotografi, montor, pelapisan logam dan sebagainya.

Untuk mencapai tujuan yang pertama, yaitu menumbuhkembangkan keimanan dan ketaqwaan kepada Tuhan YME, tidak semudah untuk mencapai dua tujuan di atas, karena berkembangnya IMTAQ bukan semata-mata karena dogma/doktrin, melainkan karena pemahaman yang berkembang berdasarkan keberadaan, keindahan, dan keteraturan alam ciptaan-Nya. Salah satu faktor penting untuk mencapai tujuan tersebut adalah cara pandang guru tentang sains, karena akan menentukan arah pembelajaran sains. Guru harus mempunyai sudut pandang yang menyeluruh tentang sains, yaitu sains sebagai cara berpikir (a way of thinking) untuk memeroleh pemahaman tentang alam dan sifat-sifatnya, cara menyelidiki ( $a$ way of investigating) fenomena-fenomena alam, dan sebagai batang tubuh pengetahuan (a body of knowledge) yang dihasilkan dari keingintahuan (inquiry) orang. Menggunakan pemahaman akan aspek-aspek yang fundamental tentan sains, seorang guru sains akan terbantu ketika menyampaikan gambaran yang lebih lengkap dan menyeluruh tentang semesta sains yang akan menumbuhkan sikap pengaguman kepada Tuhan YME dan menanamkan keyakinan kepada kebesaran Tuhan YME berdasarkan keindahan yang terkandung dalam aturan alam ciptaan-Nya [3].

Persyaratannya adalah para guru (sains) wajib membekali diri tidak hanya dengan penguasaan materi sains, tetapi juga wawasan keimanan dan ketaqwaan (imtaq), sehingga dapat mengintegrasikan wawasan imtaq ke dalam pembelajaran sains. Guru sains yang demikian itulah yang dapat mempersiapkan siswanya untuk menjadi masyarakat yang melek IPTEK, berakhlak mulia. .

\section{PEMBELAJARAN BERORIENTASI IMTAQ}

Tujuan pendidikan untuk menumbuhkembangkan iman dan taqwa kepada Tuhan Yang Maha Esa merupakan tujuan pendidikan yang paling penting yang ditandai dengan selalu muncul pertama sebagai tujuan pendidikan (sains) pada setiap kurikulum mata pelajaran sains untuk semua jenis dan jenjang pendidikan. Sebagai contoh, dalam Kurikulum 2006 (KTSP), disebutkan bahwa “ Mata Pelajaran IPA di $\mathrm{SD} / \mathrm{MI}$ antara lain bertujuan agar peserta didik memperoleh keyakinan terhadap kebesaran Tuhan Yang Maha Esa berdasarkan keberadaan, keindahan dan keteraturan alam ciptaan-Nya, [4]. Pernyataan di atas, menunjukkan bahwa pembelajaran sains, harus digunakan sebagai alat untuk menjamin pertumbuhan keimanan dan ketaqwaan siswa pada Tuhan Yang Maha Esa. Dalam Kurikulum 2006 untuk SMP/M.Ts tertulis fungsi pembelajaran sains adalah untuk menanamkan keyakinan terhadap Tuhan Yang Maha Esa".

Meskipun tujuan tersebut selalu diletakkkan sebagai tujuan pertama, namun perolehan siswa pada pembelajaran sains khususnya pada tingkat pendidikan dasar dan menengah masih sebatas pengetahuan tentang sains dan sedikit keterampilan bagi siswa yang pernah dilatih gurunya.

Sulitnya tercapai tujuan pendidikan sains untuk menanamkan keyakinan kepada Tuhan YME., disebabkan oleh banyak faktor, antara lain: (1) Pembelajaran sains yang dilakukan oleh guru di sekolah belum semuanya mampu untuk mengkaitkan materi pembelajarannya dengan aspek IMTAQ, (2) Banyak guru sains yang belum mau mengkaitkan materi pelajaran sains dengan aspek IMTAQ, (3) Buku-buku pelajaran sain yang dipakai saat ini belum banyak ( kalau memang ada) yang mengkaitkan materi pelajaran sains dengan aspek IMTAQ, dan (4) nampaknya juga pemerintah kurang serius dalam melaksanakan amanat yang tertuang dalam kurikulum. Saat ini, tujuan pembelajaran (sains) yang utama bagi guru, sekolah, dan pemerintah 
J. Pijar MIPA, Vol. III No.1, Maret $2008: 35$ - 38 .

ISSN 1907-1744

adalah mengejar ketercapaian ukuran kelulusan baik kelululusan pada ujian nasional maupun ujian sekolah.

\subsection{Indikator Ketercapaian}

IPTEK pada hakikatnya untuk meningkatkan keterampilan sebagai upaya untuk meningkatkan kualitas hidupn, sedangkan IMTAQ berfungsi untuk meningkatkan nilai moral dan kebijaksanaan.

Di bawah ini, beberapa indikator pembelajaran sains yang berorientasi IMTAQ telah tercapai, bilamana dalam diri peserta didik telah muncul kesadaran bahwa:

a. Ilmu yang dipahami manusia amat sedikit.

Kesadaran bahwa IPTEK yang dapat dimiliki manusia amat sangat terbatas dibandingkan dengan IPTEK Tuhan YME. Untuk menamkan sikap ini, dapat dilakukan dengan cara mengajak peserta didik untuk mengikuti perkembangan IPTEK itu sendiri. Misalnya dalam ilmu kimia, dapat disampaikan kepada peserta didik bahwa kurang lebih 30 ribu pertahun senyawa-senyawa kimia baru dapat disintesis oleh manusia, dan jumlah tersebut terus mengalami peningkatan. Jumlah abstrak hasil penelitian yang dapat dibuat berdasarkan hasil penelitian tidak kurang dari 1000 halaman per minggu.

Dalam bidang biologi dari tahun ke tahun, semakin canggih alat yang digunakan semakin banyak virus baru yang berhasil diidentifikasi, semakin banyak vaksin baru yang berhasil dibuat. Demikian juga halnya dalam bidang fisika, astronomi dan lain-lain memperlihatkan perkembangan yang luar biasa cepatnya. Hal ini, tentu akan membangkitkan kesadaran akan kebenaran Firman Allah dalam Surat Luqman ayat 27, yang artinya "Seandainya kayu-kayu yang ada di bumi dijadikan pena dan lautan ada di bumi, ditambah tujuh lautan lagi, dijadikan tinta maka tidaklah habis ilmu Allah ditulis. Sungguh Allah maha perkasa dan maha bijaksana" [5].

b. Kesadaran ketergantungan pada rahmat dan belas kasih dari Tuhan YME.

Dengan pemahaman sains yang baik, akan muncul kesadaran bahwa keberadaan kita, keberadaan mahluk Tuhan YME semata-mata karena adanya rahmat dan kasih sayang Tuhan YME. Untuk mencapai indikator ini, guru dapat memberikan beberapa contoh berkenaan dengan rahmat dan kasih sayang Tuhan kepada mahluknya. Sebagai contoh, misalnya pemahaman tentang air $\left(\mathrm{H}_{2} \mathrm{O}\right)$. Air adalah salah satu moplekol yang dapat membentuk ikatan hidrogen. Karena air membentuk ikatan hidrogen, maka air pada suhu kamar masih berbentuk cair. Bila air tidak membentuk ikatan hidrogen, maka pada suhu $100 \mathrm{C}$ di bawah nol sudah mendidih, akibatnya tidak akan pernah ada mahluk yang dapat hidup dimuka bumi. Karena ikatan hidrogen, tersebut, air dalam bentuk es (padat) mempunyai volume yang lebih kecil, sehingga berat jenis turun, akibatnya adalah es terapung di air. Apa yang akan terjadi bila volume air dalam bentuk es lebih kecil seperti senyawa lainnya ?, tentu tidak akan banyak orang bepergian dengan kapal laut, karena akan menghadapi hambatan dalam perjalanannya.

Makanan yang kita makan adalah hasil dari tumbuhan melalui fotosintesis. Fotosintesis dapat dapat terjadi karena adanya sinar matahari. Bagaimana kalau semua tumbuh- tumbuhan tidak mmau melakukan fotosintesis dan tidak menghasilkan karbohidrat untuk manusioa dan khwewan. Berbagai senyawa dapat disintesis di laboratorium, namun sampai saat ini manusia belum mampu melakukan sintesis beras di laboratorium. Dan bila mampu, tentu akan memerlukan biaya yang sangat mahal. Demikian juga halnya dengan tumbuhan mogok tidak menghasilkan oksigen, tentu semua hewan akan mati .

\section{c. Kesadaran bahwa bahwa yang ditetapkan oleh Tuhan Yang Maha Esa adalah yang terbaik bagi kita semua.}

Dalam ilmu kimia atau biologi, dapat kita aketahui bahwa makanan yang kita makan akan diubah menjadi energi dan bila energi yang diperoleh tidak digunakan, maka akan disimpan terutama dalam bentuk lemak dan lemak inilah yang menyebabkan orang menjadi gemuk. Dalam kaitan dengan penyimpanan energi ini, guru dan siswa dapat mempertanyakan dan mencari jawaban "mengapa kelebihan energi itu disimpan sebagai lemak, tidak dalam bentuk yang lain, seperti karbohidrat ?"

Kita tahu bahwa energi yang dihasilkan 1 gram lemak= 2,2727 x energi yang dihasilkan oleh 1 gram karbohidrat. Bila energi disimpan dalam bentuk karbohidrat, maka berat akan bertambah 2,2727 kali jumlah lemak yang disimpan. Sebagai contoh, seorang ibu dengan berat badan normal $45 \mathrm{~kg}$, karena makan berlebihan, maka beratnya menjadi 60 $\mathrm{kg}$ dan kelebihan energi ini disimpan dalam bentuk sebagai lemak. Berat badan ibu tersebut menjadi $45 \mathrm{~kg}+(15)(2.2727)$ $=79 \mathrm{~kg}$. Bila energi disimpan dalam bentuk karbohidrat, maka burung-burung mungkin tidak akan bisa terbang.

d. Kesadaran bahwa larangan dan perintah Tuhan sangat bermanfaat.

Tuhan melarang manusia untuk meminum minuman keras, seperti minuman yang mengandung alkohol. Mengapa Tuhan melarangnya ? Dengan sains dapat disampaikan bahwa alkohol yang diminum akan masuk ke dalam tubuh. Sebanyak 90-98 persen alkohol tersebut masuk ke dalam lambung dan usus, dan sisanya 2-10 persen yang dikeluarkan melalui urine, keringat, dan pernapasan. Dalam waktu paling lama 60 menit, alkohol tersebut masuk ke dalam aliran darah melalui proses difusi dengan orde reaksi satu. Selanjutnya akan terjadi metabolisme alkohol dengan orde reaksi nol terutama di dalam hati/liver menghasilkan asetsldehida, asam asetat, air, dan karbondioksida. Asetal dehida adalah senyawa kimia, sepupu dari formalin yang sangat beracun yang dapat merusak liver/hati. Metabolisme alkohol juga akan menyebabkan terjadinya akumulasi alkohol dalam darah yang bila mencapai konsentrasi 5,5 gram per liter akan menyebabkan kematian yang fatal.

Dengan menyampaikan fakta ilmiah seperti di atas, diharapkan pada diri peserta didik akan timbul kesadaran semua larangan Tuhan sangat bermanfaat bagi kebahagian hidup. Hal ini, juga sesuai dengan firman Tuhan dalam AlQur'an Surat Al Ma'dah, ayat 90-91 yang menyebutkan " "Wahai orang-orang yang beriman! Sesungguhnya minuman beralkohol, adalah kotor dan pekerjaan syetan [5]. Maka jauhilah agar kamu memperoleh kejayaan". Demikian pula halnya dengan perintah yang ditetapkan oleh Tuhan Yang Maha Esa sangat bermanfaat, seperti memakan makanan yang halal dan bergizi. 
e. Kesadaran akan keteraturan alam dengan segala isinya.

Keteraturan peredaran bumi dalam mengedari matahari sehingga terjadi malam dan siang secara silih berganti yang menyebabkan hujan, angin, pergantian musim dan sebagainya.

\subsection{Percaya kepada yang ghaib}

Percaya kepada yang ghaib merupakan salah satu sendi keimanan. Untuk menanmkan keyakinan ini kepada siswa dapat dilakukan melalui pembelajaran tentang arus listrik, karena muatan listrik merupakan sesuatu yang tidak dapat dilihat (ghaib), tetapi keberadaannya harus diyakini. Demikian juga dengan beriman kepada hari akhir dapat disipkan pada pembelajaran tentang alam semesta, tatasurya, jagat raya termasuk matahari yang akan kehabisan energi dan menjadi padam dan mengkerut menjadi benda super padat yang memiliki medan gravitasi tak terhingga. Akibat kejadian tersebut adalah semua benda langit (planet, satelit) akan hancur dan masuk ke dalam medan gravitasi benda super padat tersebut. Saat itulah kemungkinan yang disebut sebagai hari kiamat, seperti yang tertera dalam dalam Al-Qur'an Surat At-Takmir ayat 1-3 yang menyebutkan bahwa: "Apabila matahari hilang cahayanya, dan apabila bintang-bintang berguguran, apabila gunung-gunung menjadi debu [5].

\section{III.PENUTUP}

Pengembangan keimanan dan ketaqwaan kepada Tuhan YME, atau pengembangan akhlak merupakan tujuan dan sasaran utama pendidikan saat ini. Oleh sebab itu, keberhasilan pembangunan pendidikan harus dilihat dari sikap dan perilaku peserta didik dalam kehidupan seharihari, tidak cukup dengan hanya mengukur ketercapaian indikator yang hanya mengutamakan pengusaan ilmunya.

Persoalannya adalah, sejauhmana kemampuan dan kemauan guru dan atau calon guru (sains) mengembangkan pembelajaran yang berorintasi iptek, karena materi pembelajaran sains penuh dengan penuh dengan materi untuk peningkatan IPTEK. Atas dasar itu, maka guru dan calon guru harus banyak belajar materi pelajaran sesuai dengan bidang ilmunya dan menambah wawasannya tentang iman dan taqwa, mengerjakan semua perintah dan menjauhi semua larangan Tuhan, karena pembelajaran IMTAQ harus lebih banyak dengan suri tauldan yang baik, dan perlu kesadaran pada diri guru atau calon guru sains bahwa guru itu adalah profesi nurani.

\section{DAFTAR PUSTAKA}

[1] Effendy, 2008. " Kimia sebagai alat untuk meningkatkan Keimanan dan Ketaqwaan Siswa" Makalah" pada Seminar Pengembangan Pembelajaran Kimia. Mataram: PMIPA FKIP Unram.

[2] Science Technology Literacy in the SETS (Science, Environment, Technology and Society) Perspective. Paper presented in the regional workshop on scientific and technological Ilitercy for all conducted by SEAMEO RECSAM in collaboration with UNESCO and ICASE. Penang.
[3] Naskah Keterkaitan 10 Mata Pelajaran Di SMU dengan Imtaq. (2000), Jakarta: Depdiknas Dikdasmen Bag. Proyek Peningkatan Wawasan Keagamaan Guru.

[4] Rodatun Widayati, 1998. Urgensi Penelusuran bakat Keilmuwan Siswa Madrasah Aliyah. Jakarta: Ditjen Bagais Depag RI.

[5] Al-Quran dan Terjemahnya, 1977. Jakarta: PT. Bumi Restu Binadja, A. 1999. 